\title{
TANGGAPAN ANATOMIS DARI BEBERAPA SUMBER BENIH Acacia manigum Willd. TERHADAP KONDISI CEKAMAN GARAM
}

Anatomical Response of several Acacia mangium Willd. seed sources under salinity stress

\author{
Dwi Kartikaningtyas ${ }^{1}$, Octiva Quirena ${ }^{2}$, Suharyanto ${ }^{2}$, Sri Sunarti ${ }^{1}$, \\ ${ }^{1}$ Balai Besar Penelitian Bioteknologi dan Pemuliaan Tanaman Hutan \\ 1) Jl. Palagan Tentara Pelajar Km 15, Purwobinangun, Pakem, Sleman, Yogyakarta 55582 \\ 2) Fakultas Biologi Universitas Gadjah Mada \\ Jl. Teknika Selatan, Sekip Utara, Yogyakarta 5528; Telp. (0274) 580839 \\ e-mail : akitrak@gmail.com
}

\begin{abstract}
Along with the increase of forest plantation development to supply raw material for industry, the utilization of marginal land with high salinity is likely to be an alternative for the plantation of A. mangium. In an effort to increase the improvement of A. mangium to be extensively planted on the widely alternative land, breeding programs were conducted to get trees of $\mathrm{A}$. mangium which are tolerant to environmental stress, such as salt stress. The purpose of this study was to observe the anatomical response of A. mangium collected from several seed sources to salinity stress as a basis for salt tolerance breeding program. The trial consisted of four seed sources arranged in Completely Randomized Design with four level salt stresses (0;22; 26 and $30 \mathrm{~g} / \mathrm{l})$ and 3 replications. The four tested seed sources are two seedling seed orchard (SSO) originated from Papua New Guinea provenance (namely group A and $B$ ), one SSO originated from Far North Queensland provenance (group C) and one SSO originated from a combining both provenances (group E). The treatment is given by watering the seedlings from each provenance with saline solution in accordance with a predetermined concentration of $200 \mathrm{ml}$ per day for 4 months. The observed parameters were stomatal index, length dan width of stomata, number and diameter of trachea, and chlorophyll content. The results showed that in general the differences in salt concentration provided a significant effect on anatomical response of A. mangium. Except for the length of stomata, seed source variations were significantly different for all parameters. Meanwhile, seed sources $x$ salt level interaction did not significantly affect the length and width of stomata. The higher the salt concentration, the lower the stomatal index and chlorophyll content. Conversely, the higher the salt concentration, the higher the amount of the tracheid. However the differences in salt concentration did not give a significant effect on diameter of tracheid. Overall, among the four tested seed sources, group B which is originated from Papua New Guinea provenancewas found to be the most tolerant seed sources to salt stress.
\end{abstract}

Keyword : A. mangium Willd, seed sources, salt stress, salt tolerance, tree improvement 


\begin{abstract}
ABSTRAK
Sejalan semakin meningkatnya pembangunan hutan tanaman untuk pemenuhan kebutuhan bahan baku industri, pemanfaatan lahan marginal dengan salinitas yang tinggi berpeluang menjadi lahan alternatif dalam pengembangan Acacia mangium. Dalam upaya meningkatkan pengembangan A.mangium menjadi tanaman yang ditanam secara luas di berbagai lahan alternatif, dilakukan program pemuliaan untuk mendapatkan tanaman unggul $\mathrm{A}$. mangium yang tahan terhadap cekaman lingkungan, seperti cekaman garam. Tujuan dari penelitian ini adalah mengetahui tanggapan anatomis tanaman $A$. mangium dari beberapa sumber benih terhadap cekaman garam sebagai dasar dalam penentuan program pemuliaan terhadap toleransi garam. Penelitian ini terdiri dari 4 sumber benih yang dirancang dalam rancangan acak lengkap dengan 3 ulangan dan 4 taraf cekaman garam $(0 ; 22 ; 26$ dan 30 g/l). Empat sumber benih yang diuji adalah kebun benih semai (KBS) generasi pertama yang berasal dari provenan Papua New Guinea (grup A dan B), satu KBS berasal dari Queensland Utara (grup C) dan satu KBS yang berasal dari kombinasi diantara kedua provenan (grup E). Perlakuan diberikan dengan penyiraman semai dari masing-masing provenan dengan larutan garam sesuai dengan konsentrasi yang telah ditentukan sebanyak $200 \mathrm{ml}$ setiap harinya selama 4 bulan. Parameter yang diamati meliputi indeks stomata, panjang dan lebar stomata, jumlah dan diameter trakeid serta kadar klorofil. Hasil penelitian menunjukkan bahwa perbedaan konsentrasi garam memberikan pengaruh yang nyata terhadap tanggapan anatomis $A$. mangium. Kecuali pada panjang stomata, perbedaan sumber benih memberikan pengaruh yang nyata terhadap semua sifat. Sementara itu, sumber benih x kadar garam tidak memberikan pengaruh yang nyata terhadap panjang dan lebar stomata. Semakin tinggi konsentrasi kadar garam, semakin rendah nilai indek stomata dan kadar klorofil. Sebaliknya semakin tinggi konsentrasi kadar garam, semakin tinggi jumlah trakeid. Namun demikian, perbedaan konsentrasi garam tidak memberikan pengaruh yang nyata terhadap diameter trakeid. Secara keseluruhan, dari keempat sumber benih yang digunakan, KBS grup B -yang berasal dari provenan Papua New Guinea- menunjukkan toleransi yang paling baik.
\end{abstract}

\title{
Kata kunci: $A$. mangium, sumber benih, cekaman garam, toleransi garam, pemuliaan pohon
}

\section{PENDAHULUAN}

Acacia mangium Willd. merupakan salah satu jenis tanaman cepat tumbuh yang pada umumnya hidup pada lahan dengan drainase baik dan bereaksi masam / pH rendah (Hardiyanto, 2004), dan mampu tumbuh pada lahan yang sulit/kurang subur (Pinyopusarerk et al.,1993). Keunggulan lain yang dimiliki oleh Acacia mangium adalah mempunyai sifat kayu yang dapat dipergunakan sebagai bahan baku pulp, pertukangan, kontruksi ringan dan jenis ini mempunyai teknik silvikultur yang mudah (Hardiyanto, 2004). Oleh karena itu, A. mangium banyak digunakan dalam pengembangan Hutan Tanaman Industri (HTI) untuk memenuhi kebutuhan bahan baku pembuatan pulp. 
Sebagai upaya untuk memenuhi ketersediaan bahan baku industri yang semakin meningkat, ekstensifikasi pengembangan hutan tanaman jenis A. mangium pada berbagai kondisi lahan perlu dilakukan. Salah satu alternatif dalam pengembangan hutan tanaman ini adalah pemanfaatan lahanlahan marginal yang memiliki salinitas tinggi. Salinitas didefinisikan sebagai adanya garam terlarut dalam konsentrasi yang berlebihan dalam larutan tanah (Yuniati, 2004). Salinitas yang cukup tinggi akan mengakibatkan adanya cekaman yang akan menimbulkan dampak yang berbeda pada setiap tanaman. Pada tanaman kacang merah, pelebaran daun terhambat oleh salinitas karena berkurangnya tekanan turgor sel (Neuman et al., 1988). Tanggapan yang berbeda ditunjukkan oleh tanaman kedelai bahwa cekaman garam berpengaruh terhadap jumlah trikoma, ukuran xylem maupun ketebatan kortek (Dolatabadian et al., 2011). Pada tanaman Eucalyptus occidentalis juga menunjukkan tanggapan yang berbeda pada uji terkendali maupun uji lapangan terhadap tekanan garam (Hendarti, 2010). Tanggapan yang berbeda ditunjukkan oleh provenan yang berbeda pada setiap perlakuan kadar garam (Hendarti, 2010).
Balai Besar Penelitian Bioteknologi dan Pemuliaan Tanaman Hutan melalui serangkaian strategi pemuliaannya, telah berhasil meningkatkan produktivitas volume tegakan A. mangium hingga mencapai Mean Annual Increment (MAI) $37 \mathrm{~m} 3 / \mathrm{ha} /$ th $-40 \mathrm{~m} 3 / \mathrm{ha} /$ th dalam dua generasi siklus pemuliaan (Nirsatmanto dkk, 2003). Sebagai upaya untuk meningkatkan keunggulan sifat A. mangium dalam peningkatan pertumbuhan tanaman serta diversifikasi potensi pemanfaatannya pada lahan-lahan marginal, maka perlu dilakukan pengujian lebih lanjut daya adaptabilitasnya pada kondisi cekaman lingkungan, salah satu diantaranya terhadap cekaman garam. Tujuan dari penelitian ini adalah mengetahui tanggapan anatomis tanaman A. mangium dari beberapa sumber benih terhadap cekaman garam pada tingkat semai sebagai salah satu dasar dalam penyusunan program pemuliaan terhadap cekaman lingkungan.

\section{BAHAN DAN METODE}

\section{A. Bahan dan Alat}

Bahan yang dipergunakan dalam penelitian ini adalah bibit $A$. mangium Willd. umur 8 bulan yang berasal dari 4 sumber benih yang berbeda (Tabel 2). dan larutan garam. 
Larutan garam dibuat dengan melarutkan garam krasak kedalam akuades dengan berbagai perbandingan (Tabel 1).

Tabel 1. Perbandingan pembuatan larutan garam

\begin{tabular}{cc}
\hline $\begin{array}{c}\text { Konsentrasi } \\
\text { Garam }(\mathrm{g} / \mathrm{l})\end{array}$ & $\begin{array}{c}\text { Garam }(\mathrm{g}): \text { Akuades } \\
(\mathrm{l})\end{array}$ \\
\hline 0 (Kontrol) & $0: 1$ \\
22 & $22: 1$ \\
26 & $26: 1$ \\
30 & $30: 1$ \\
\hline
\end{tabular}

Bahan lain yang digunakan untuk pembuatan preparat free hand section adalah alkohol 70\%, akuades, safranin, gliserin, dan kuteks. Sementara itu pembuatan preparat irisan epidermis akar dilakukan dengan metode leaf clearing menggunakan bahan kloralhidrat.

Alat yang dipergunakan dalam penelitian ini di antaranya adalah plastik takar, jangka sorong, meteran, gunting, timbangan digital, pipet ukur, pipet tetes, gelas ukur, bak preparat $20 \mathrm{~cm} \times 20 \mathrm{~cm}$, mikroskop, kaca preparat, lampu spiritus, petridish, cutter, pinset dan botol flakon.

Tabel 2. Sumber benih dan informasi sumber provenan yang dipergunakan dalam penelitian

\begin{tabular}{|c|c|c|c|}
\hline No & Sumber Benih & Lokasi & Provenan \\
\hline \multirow{5}{*}{1} & \multirow{5}{*}{$\begin{array}{c}\text { Kebun Benih Semai } \\
(\text { grup A })\end{array}$} & \multirow{5}{*}{ Kalimantan Selatan } & Dimissisi (PNG) \\
\hline & & & Derideri E Morehead (PNG) \\
\hline & & & Guban NE Morehead (PNG) \\
\hline & & & Bimadebun (PNG) \\
\hline & & & Arufi Village (PNG \\
\hline \multirow{3}{*}{2} & \multirow{3}{*}{$\begin{array}{c}\text { Kebun Benih Semai } \\
\text { (grup B) }\end{array}$} & \multirow{3}{*}{ Sumatera Selatan } & Oriomo $(\mathrm{PNG})$ \\
\hline & & & Wipim (PNG) \\
\hline & & & Kini (PNG) \\
\hline \multirow{2}{*}{3} & \multirow{2}{*}{$\begin{array}{c}\text { Kebun Benih Semai } \\
\text { (grup C) }\end{array}$} & \multirow{2}{*}{ Kalimantan Selatan } & Claudie River (FNQ) \\
\hline & & & $135 \mathrm{~K} N(\mathrm{FNQ}$ \\
\hline \multirow{12}{*}{4} & \multirow{12}{*}{$\begin{array}{c}\text { Kebun Benih Semai } \\
\text { (grup E) }\end{array}$} & \multirow{12}{*}{ Jawa Tengah } & Dimissisi (PNG) \\
\hline & & & Derideri E Morehead (PNG) \\
\hline & & & Guban NE Morehead (PNG) \\
\hline & & & Bimadebun (PNG) \\
\hline & & & Arufi Village (PNG \\
\hline & & & Boite Ne Morehead (PNG) \\
\hline & & & Wipim (PNG) \\
\hline & & & Kini (PNG) \\
\hline & & & Claudie River (FNQ) \\
\hline & & & $135 \mathrm{~K} \mathrm{~N}(\mathrm{FNQ})$ \\
\hline & & & Poscoe River (FNQ \\
\hline & & & Cassowary CK (FNQ) \\
\hline
\end{tabular}




\section{B. Metode Penelitian}

\section{Prosedur Kerja}

3. Penelitian diawali dengan pemilihan bibit $A$. mangium umur 8 bulan dari 4 sumber benih yang mempunyai kondisi pertumbuhan hampir sama. Bibit selanjutnya dipindahkan ke dalam polibag besar $(15 \times 25 \mathrm{~cm})$ yang berisi campuran media tanah dan kompos dengan perbandingan $2: 1$ dengan berat total media pada masing-masing polibag sebesar 5,5 kg. Setelah dipindahkan dalam polibag besar, bibit diaklimatisasi terlebih dahulu selama 1 bulan di dalam greenhouse. Untuk mengetahui kondisi awal pertumbuhan tanaman sebelum diberikan perlakuan, pengukuran data awal dilakukan dengan mengukur tinggi dan diameter bibit, jumlah tunas dan jumlah daun semu.

4. Rancangan percobaan yang digunakan dalam penelitian ini adalah rancangan acak lengkap dengan pola faktorial 4 x 4 pada 4 sumber benih $A$. mangium dengan 4 taraf konsentrasi garam. Konsentrasi garam yang diberikan yaitu $0 \mathrm{~g} / 1$ (K0), $22 \mathrm{~g} / \mathrm{l}(\mathrm{K} 1), 26 \mathrm{~g} / \mathrm{l}(\mathrm{K} 2)$ dan $30 \mathrm{~g} / \mathrm{l}$ (K3), setiap bibit disiram dengan larutan garam sebanyak $200 \mathrm{ml}$ setiap harinya selama 4 bulan. Penentuan konsentrasi garam berdasarkan pada konsentrasi garam terendah $(0 \mathrm{~g} / \mathrm{l})$ sampai dengan mendekati konsentrasi garam air laut (30 g/l), karena menurut Nybakken (1992) bahwa salinitas air laut adalah 3,5\% atau $35 \mathrm{~g} / 1$. Selama kegiatan penelitian tidak dilakukan pemeliharaan berupa penyiraman dengan air biasa.

5. Pengamatan anatomi dilakukan pada waktu 1 bulan setelah perlakuan dengan pengukuran beberapa parameter, diantaranya adalah :

a. Stomata

Pengamata stomata dilakukan dengan pembuatan preparat menggunakan metode leaf clearing yang kemudian dihitung besarnya indeks stomata, panjang dan lebar stomata, menurut Palit (2008) dengan pendekatan :

$$
\text { Indeks stomata }=\frac{\text { jumlah stomata }}{\text { jumlah stomata }+}
$$

Pembuatan preparat pada pengamatan stomata menggunakan daun keempat yang kemudian disayat tipis dan difiksasi menggunakan alkohol 70\% selama \pm 24 jam hingga berwarna putih. Setelah itu larutan alkohol 
diganti dengan larutan kloralhidrat selama \pm 2 hari atau hingga daun transparan kemudian dipindahkan ke gelas benda dan diberi warna dengan safranin selanjutnya dilakukan pengamatan dan penghitungan jumlah stomata persatuan luas $\mathrm{cm}^{2}$.

b. Tracheid

Pengamatan trakeid dilakukan dengan pembuatan preparat melintang akar dengan metode free hand section (Johansen, 1940) dengan modifikasi yang kemudian dihitung jumlah trakeid per satuan luas $\mathrm{cm}^{2}$, diameter besar dan diameter kecil trakeid.

Preparat menggunakan akar yang telah difiksasi alkohol $70 \%$ dan dipotong $1 \mathrm{~cm}$ kemudian diiris tipistipis dan direndam kedalam akuades. Irisan yang didapat diletakkan kedalam gelas preparat dan ditetesi safranin kemudian dicuci dengan akuades. Untuk memastikan bahwa pengirisan preparat sudah sesuai, preparat diamati dengan mikroskop terlebih dahulu. Terakhir preparat ditetesi gliserin, ditutup dengan gelas penutup dan diberi pewarna kuku (kutek). c. Pengamatan Klorofil

Analisis terhadap klorofil dilakukan dengan penghitungan kadar klorofil. Kadar klorofil menurut Harborne (1987) dapat dihitung dengan pendekatan :

Kadar klorofil $\mathrm{a}=$ 12,21 (abs 663) - 2,81 (abs 646) mg/l Kadar klorofil $b=$ 20,13 (abs 646) - 5,03 (abs 663) mg/l Kadar klorofil total $=$ $17,3(\operatorname{abs} 646)+7,18($ abs 663) $\mathrm{mg} / 1$

Dengan abs adalah nilai absorbansi pada panjang gelombang 646 $\mathrm{nm}$ dan $663 \mathrm{~nm}$ yang tertera di spektrofotometer. Selanjutnya kadar klorofil yang telah diukur dikonversi dalam satuan $\mathrm{mg} / \mathrm{g}$ dengan pendekatan :

$$
\frac{10 / 1000 \times \text { kadar klorofil }}{0,1 \mathrm{mg} / \mathrm{g}}
$$

\section{Analisis Data}

Data yang diperoleh dianalisis dengan Analysis of Variance (ANOVA). 


\section{HASIL DAN PEMBAHASAN}

Perlakuan cekaman garam pada tanaman A. mangium telah memberikan tanggapan pada setiap semai yang diamati (gambar 1). Terganggunya pertumbuhan pada semai yang diamati menunjukkan bahwa adanya cekaman garam telah menganggu metabolisme tanaman. Dengan semakin bertambahnya konsentrasi garam yang diberikan maka tanggapan yang ditunjukkan juga berbeda. Hal ini terlihat dari laju pertumbuhan tanaman yang semakin rendah seiring dengan bertambahnya konsentrasi garam.

Pengamatan anatomis A. mangium sebagai tanggapan adanya cekaman garam dilakukan pada tanaman yang berasal dari 4 sumber benih, yaitu kebun benih semai yang berasal dari provenan PNG (grup A dan B),kebun benih semai yang berasal dari provenan FNQ (grup C) dan kebun benih semai yang berasal dari kombinasi provenan PNG dan FNQ (grup E).

\section{A. Anatomi Stomata}

Pengamatan terhadap anatomi stomata menunjukkan adanya pengaruh yang nyata dari perlakuan yang diberikan terhadap indeks stomata, lebar dan panjang stomata, walaupun interaksi antara sumber benih dan konsentrasi garam tidak menunjukkan pengaruh yang nyata terhadap lebar dan panjang stomata (Tabel 3).

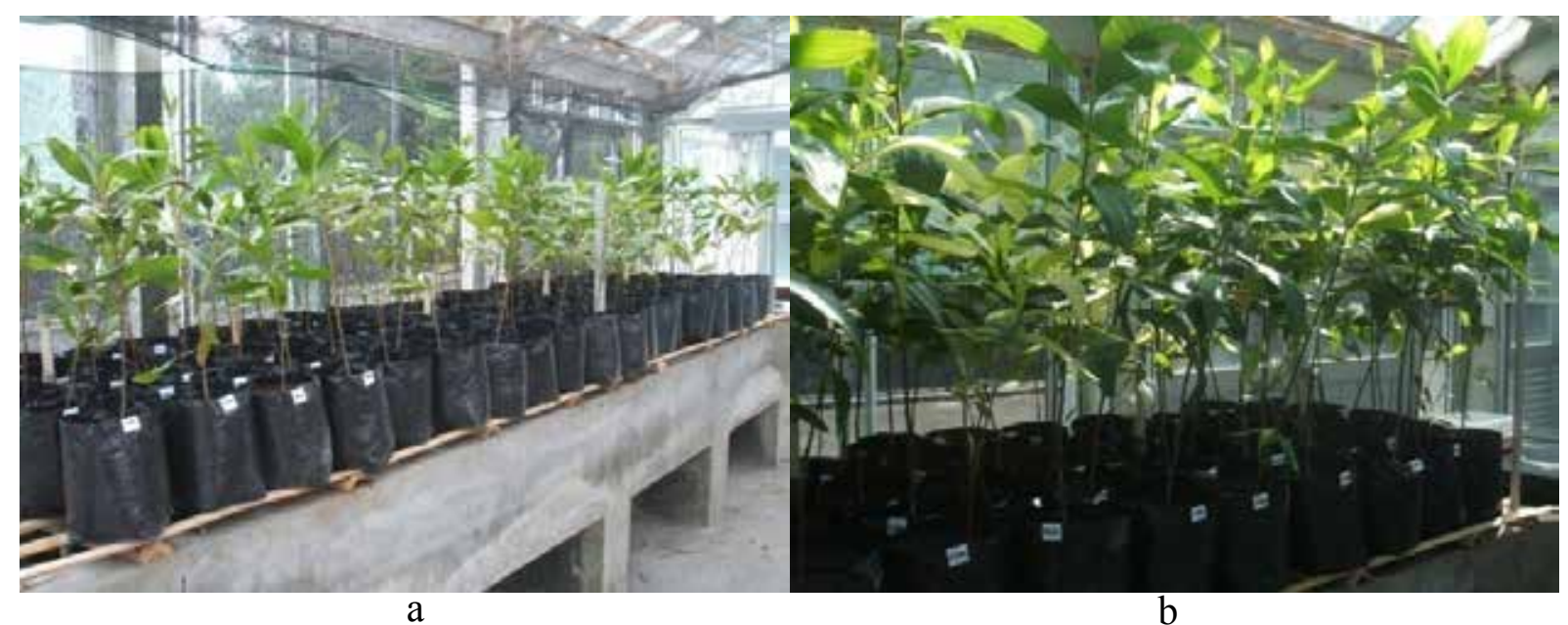

Gambar 1. kondisi tanaman Acacia mangium Willd. sebelum perlakuan (a) dan setelah perlakuan (b) 
Tabel 3. Hasil analis varians pengaruh perlakuan sumber benih dan cekaman garam terhadap stomata

\begin{tabular}{|c|c|c|c|c|c|c|c|}
\hline \multirow{2}{*}{ Sumber Variasi } & \multirow{2}{*}{$\mathrm{db}$} & \multicolumn{2}{|c|}{ Indeks Stomata } & \multicolumn{2}{|c|}{ Lebar Stomata } & \multicolumn{2}{|c|}{ Panjang Stomata } \\
\hline & & $\mathrm{JK}$ & KT & $\mathrm{JK}$ & $\mathrm{KT}$ & $\mathrm{JK}$ & KT \\
\hline Sumber Benih & 3 & .002 & $.001 *$ & 8,096 & $2,699 *$ & 7,374 & $2,458^{\mathrm{ns}}$ \\
\hline Konsentrasi & 3 & .008 & $.003 *$ & 12,046 & $4,015^{*}$ & 124,107 & $41,369^{*}$ \\
\hline SB * Kons & 9 & .003 & $.000 *$ & 10,047 & $1,116^{\mathrm{ns}}$ & 26,285 & $2,921^{\mathrm{ns}}$ \\
\hline Error & 32 & .003 & 8.99E-02 & 18,827 & .588 & 47,973 & 1,499 \\
\hline
\end{tabular}

Keterangan : $*$ = Berbeda nyata; ns = Tidak berbeda nyata

Pengamatan pengaruh kadar garam terhadap anatomi stomata menunjukkan terjadi penurunan nilai indeks stomata, panjang stomata maupun lebar stomata seiring dengan penambahan konsentrasi garam. Tingkat penurunan indeks stomata maupun ukuran stomata menunjukkan perbedaan antar sumber benih yang diuji. Penurunan indeks stomata dan lebar stomata terbesar terjadi pada grup E, yaitu dari 0,15 menjadi 0,09 untuk indeks stomata dan dari $14,20 \mu \mathrm{m}$ menjadi $13,80 \mu \mathrm{m}$ untuk lebar stomata. Sementara itu terhadap panjang stomata, penurunan terbesar terjadi pada grup B, yaitu dari $20,60 \mu \mathrm{m}$ menjadi 17,70 $\mu \mathrm{m}$ (gambar 2).

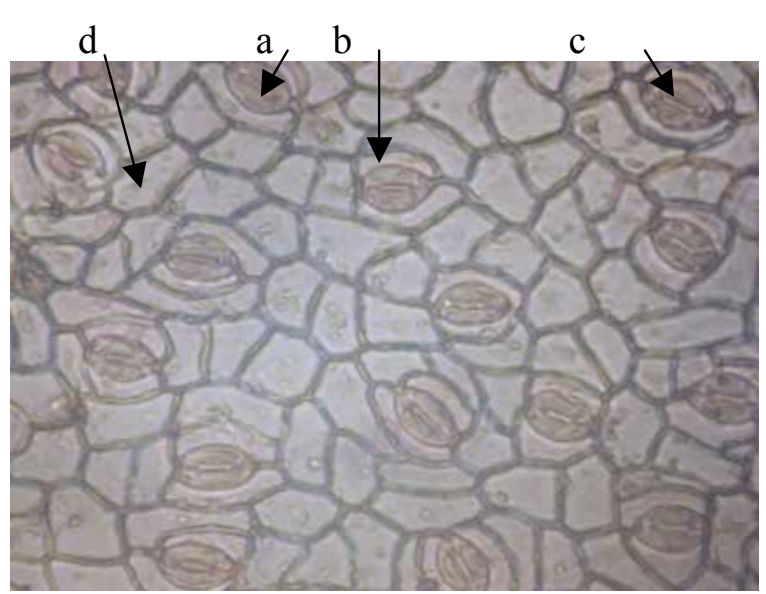

Gambar 2. Sayatan epidermis daun, (a) sel penjaga; (b) sel tetangga; (c) porus; (d) sel epidermis, menggunakan optilap perbesaran. 10.

Penambahan konsentrasi garam mengakibatkan adanya penurunan indeks stomata dan ukuran stomata (panjang dan lebar stomata) pada ke-empat sumber benih yang diamati, walaupun dengan tingkat penurunan yang berragam. Hal ini terjadi karena tanaman mengalami keracunan garam akibat konsentrasi ion yang tinggi. Selain itu konsentrasi garam yang tinggi juga mengakibatkan tanah / media mengalami hipertonis sehingga terjadi kekurangan 
air dan akhirnya tanaman mengalami cekaman kekeringan. Dalam kondisi ini, untuk bertahan hidup tanaman akan melakukan penyesuaian dengan beberapa mekanisme untuk mencegah keluarnya air secara berlebihan pada proses transpirasi yang terjadi melalui stomata, kutikula dan lentisel (Devlin, 1983). Menurut Price dan Courtis (1991), salah satu adaptasi morfologi tumbuhan untuk mengurangi transpirasi atau beradaptasi terhadap cekaman kekeringan adalah mengurangi jumlah stomata. Hal lain juga diungkapkan oleh Harjadi dan Yahya (1988), yang menyebutkan bahwa adanya cekaman garam selain mengubah aktivitas metabolisme juga menyebabkan perubahan anatomi tumbuhan yang mencakup ukuran daun yang lebih kecil, stomata yang lebih kecil per satuan luas daun, peningkatan sukulensi, penebalan kutikula dan lapisan lilin pada permukaan daun, serta lignifikansi akar yang lebih awal. Mekanisme adaptasi lain juga dilakukan dengan pola penurunan ukuran stomata (panjang dan lebar stomata) seiring dengan bertambahnya konsentrasi garam. Mengecilnya ukuran stomata pada tanaman bertujuan untuk mengurangi transpirasi, terutama pada saat kondisi tercekam. Sebagaimana diungkapkan oleh
Price \& Courtois (1991) bahwa beberapa tanaman beradaptasi terhadap cekaman kekeringan dengan cara memperkecil ukuran stomatanya. Hal inilah yang terjadi pada tanaman A. mangium, karena untuk tetap tumbuh pada kondisi cekaman garam tanaman melakukan adaptasi anatomis dengan penurunan indeks stomata maupun ukuran stomata (panjang dan lebar stomata).

Berdasarkan sumber benih yang diuji, grup B menunjukkan mekanisme penyesuaian yang paling baik pada pengamatan anatomi stomata, dan selanjutnya diikuti oleh grup A, C, D, dan E. Hal ini ditunjukkan dengan tingkat penurunan indeks dan lebar stomata yang paling kecil dibandingkan dengan sumber benih yang lain. Walaupun grup B juga mengalami tingkat penurunan terbesar pada panjang stomata, hasil analisis varians menunjukkan tidak terjadi perbedaan yang nyata antar sumber benih yang diuji pada sifat ini (Tabel 3).

\section{B. Anatomi Trakeid}

Pengaruh kadar garam terhadap anatomi trakeid, menunjukkan bahwa seluruh perlakuan dan interaksi antar perlakuan memberikan pengaruh yang nyata terhadap jumlah trakeid, diameter besar dan diameter kecil trakeid (Tabel 4). 
Tabel 4. Hasil analis varians pengaruh perlakuan sumber benih dan cekaman garam terhadap trakeid

\begin{tabular}{lrrrrrrr}
\hline \multirow{2}{*}{ Sumber Variasi } & db & \multicolumn{2}{c}{ Jml Trakeid } & \multicolumn{2}{c}{ Diameter Besar Trakeid } & \multicolumn{2}{c}{ Diameter Kecil Trakeid } \\
\cline { 3 - 8 } & & \multicolumn{1}{c}{ JK } & \multicolumn{1}{c}{ KT } & \multicolumn{1}{c}{ JK } & \multicolumn{1}{c}{ KT } & JK & KT \\
\hline Sumber Benih & 3 & $8,249,083$ & $2,749,694^{*}$ & $1,243,851$ & $414,617^{*}$ & $1,243,851$ & $414,617^{*}$ \\
Konsentrasi & 3 & $34,270,750$ & $11,423,583^{*}$ & $1,606,349$ & $535,450^{*}$ & $1,606,349$ & $535,450^{*}$ \\
SB * Kons & 9 & $3,276,750$ & $364,083^{*}$ & $6,000,830$ & $666,759^{*}$ & $6,000,830$ & $666,759^{*}$ \\
Error & 32 & $2,035,333$ & 63,604 & $1,210,653$ & 37,833 & $1,210,653$ & 37,833 \\
\hline
\end{tabular}

Keterangan : $*$ Berbeda nyata; ns = Tidak berbeda nyata

Perlakuan penambahan konsentrasi garam memberikan dampak pada kenaikan jumlah trakeid pada setiap sumber benih. Kenaikan jumlah trakeid terbesar terjadi pada grup B dengan kenaikan jumlah trakeid dari 78,67 menjadi 170 per satuan luas $\mathrm{cm}^{2}$ dan grup $\mathrm{C}$ dari 61,33 menjadi 155 per satuan luas $\mathrm{cm}^{2}$. Akan tetapi kenaikan jumlah trakeid tersebut tidak diiringi dengan kenaikan ukuran diameter besar trakeid maupun diameter kecil trakeid secara

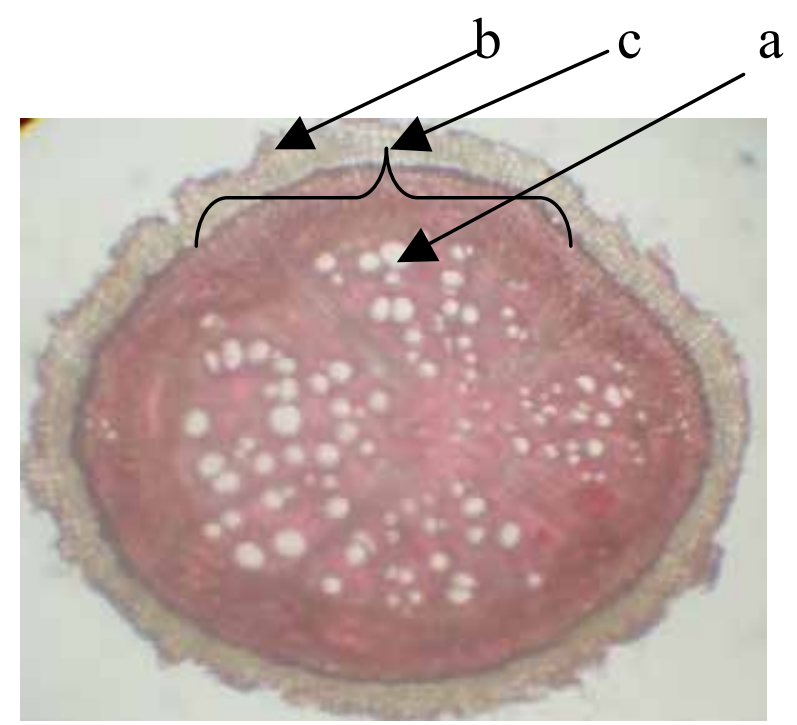

A nyata hal ini terlihat dengan perubahan ukuran diameter yang beragam pada setiap sumber benih seiring dengan penambahan konsentrasi garam.

Adanya konsentrasi garam tanah yang tinggi akan menurunkan ketersediaan air sebagai medium hara, sehingga tekanan osmosis meningkat yang berakibat pada terhambatnya penyerapan air oleh akar. Selain itu konsentrasi ion yang tinggi akan menimbulkan adanya ketidakseimbangan

Gambar 3. Irisan melintang akar (A) gambar keseluruhan dengan mikroskop cahaya perbesaran. 10; (B) trakeid akar dengan optilap perbesaran. 4. (a) trakeid; (b) korteks; (c) stele 
hara yang dapat menimbulkan toksisitas ion-ion tertentu (Levitt, 1980; Follet, 1981). Air diperoleh dari tanah melalui akar dan dikirim ke bagian lain melalui xilem, sedangkan trakeid merupakan bagian dari xilem yang berfungsi mengangkut air, sehingga apabila tanaman berada dalam kondisi lingkungan yang tidak mendukung dalam hal ini konsentrasi garam yang tinggi, maka penyerapan air akan terganggu, dan karenanaya dibutuhkan suatu mekanisme agar kebutuhan air tetap terpenuhi. Adanya penambahan jumlah trakeid seiring dengan penambahan konsentrasi garam menandakan bahwa A. mangium memiliki kemampuan ketahanan yang cukup baik terhadap cekaman garam, dengan semakin banyaknya jumlah trakeid, maka air yang diangkut semakin banyak, dengan demikian kebutuhan air akan tetap terpenuhi walaupun dalam kondisi tercekam.

Selain dengan penambahan jumlah trakeid, penyesuaian juga dilakukan dengan perubahan ukuran trakeid. Dengan bertambahnya ukuran trakeid maka mekanisme penyerapan air pada tanaman tidak terganggu. Pengukuran diameter trakeid dilakukan dengan cara mengukur trakeid terkecil dan terbesar karena dalam satu akar ukuran trakeid dapat berbedabeda. Dengan demikian ukuran trakeid yang ada merupakan selang antara ukuran terkecil hingga terbesar. Hasil pengamatan menunjukkan bahwa penyesuaian yang dilakukan oleh $A$. mangium terhadap cekaman garam tidak dilakukan dengan penambahan ukuran trakeid. Dalam kondisi tercekam, tumbuhan akan melakukan penyesuaian untuk memenuhi kebutuhan air. Mekanisme penyesuaian yang terjadi pada A. mangium adalah memperbanyak jumlah trakeid untuk pengangkutan air, sementara mekanisme penambahan ukuran trakeid tidak terjadi.

\section{Kadar Klorofil}

Pengaruh kadar garam terhadap klorofil menunjukkan adanya perbedaan yang nyata pada seluruh parameter klorofil, namun sumber benih dan interaksinya dengan konsentrasi garam tidak memberikan pengaruh yang nyata pada klorofil $b$. 
Tabel 5. Hasil analis varians pengaruh perlakuan sumber benih dan cekaman garan terhadap klorofil

\begin{tabular}{lrrrrrrr}
\hline \multirow{2}{*}{ Sumber Variasi } & \multirow{2}{*}{} & \multicolumn{2}{c}{ Klorofil a } & \multicolumn{2}{c}{ Klorofil b } & \multicolumn{2}{c}{ Klorofil Total } \\
\cline { 3 - 8 } & & \multicolumn{1}{c}{ JK } & \multicolumn{1}{c}{ KT } & \multicolumn{1}{c}{ JK } & \multicolumn{1}{c}{ KT } & \multicolumn{1}{c}{ JK } & KT \\
\hline Sumber Benih & 3 & 99,868 & $33,289^{*}$ & 10,721 & $3,574^{\text {ns }}$ & 162,871 & $54,290^{*}$ \\
Konsentrasi & 3 & 244,523 & $81,508^{*}$ & 103,179 & $34,393^{*}$ & 726,946 & $242,315^{*}$ \\
SB ${ }^{*}$ Kons & 9 & 82,426 & $9,158^{*}$ & 9,290 & $1,032^{\text {ns }}$ & 114,255 & $12,695^{*}$ \\
Error & 32 & 56,559 & 1,767 & 89,761 & 2,805 & 89,507 & 2,797 \\
\hline
\end{tabular}

Keterangan $:{ }^{*}=$ Berbeda nyata; $\mathrm{ns}=$ Tidak berbeda nyata

Pada pengamatan klorofil, kadar klorofil yang diukur meliputi jumlah klorofil a,b dan klorofil total. Secara keseluruhan terlihat bahwa dengan adanya penambahan konsentrasi garam akan menurunkan kadar klorofil baik klorofil a, klorofil b maupun kadar klorofil total. Dari pengamatan terlihat adanya penurunan kadar klorofil total tertinggi terjadi grup E dari $1,49 \mathrm{mg} / \mathrm{g}$ menjadi $0,26 \mathrm{mg} / \mathrm{g}$ dan penurunan kadar klorofil terendah terjadi pada grup B dari $1,24 \mathrm{mg} / \mathrm{g}$ menjadi $0,29 \mathrm{mg} / \mathrm{g}$.

Secara umum kadar klorofil dapat dilihat dari kadar klorofil total. Dari hasil pengamatan terlihat bahwa adanya penambahan konsentrasi garam akan diikuti dengan penurunan kadar klorofil, kadar klorofil tersebut mengalami penurunan yang bervariasi pada setiap sumber benih. Dari 4 sumber benih yang diuji, grup B mengalami penurunan kadar klorofil yang paling rendah dibandingkan dengan sumber benih yang lain.
Tanaman yang mengalami cekaman garam umumnya tidak menunjukkan tanggapan dalam bentuk kerusakan langsung, akan tetapi biasanya mengalami pertumbuhan yang tertekan dan perubahan secara perlahan dan akan timbul gejala-gejala seperti daun mengering di bagian ujung dan gejala klorosis yang dapat menyebabkan pertumbuhan sel tanaman tidak normal (Sipayung, 2003). Hal ini terjadi pada tanaman A. mangium yang diamati, yaitu terjadi penurunan kadar klorofil seiring dengan penambahan konsentrasi garam. Adanya penurunan kadar klorofil dapat dilihat secara morfologis dengan gejala klorosis pada daun muda (gambar 4), adanya klorosis akan menyebabkan terhambatnya proses fotosintesis. Selain itu adanya peningkatan kadar salinitas dapat menurunkan serapan $\mathrm{N}$ total pada tanaman Phaseolus vulgaris (Pessarakli, 1994).Nitrogen merupakan unsur utama yang berperan dalam pembentukan klorofil, sehingga dengan 
terhambatnya metabolisme Nitrogen maka akan mengganggu pembentukan klorofil. Hal serupa juga diungkapkan oleh Strogonov (1964) bahwa gangguan metabolisme Nitrogen dapat disebabkan karena adanya akumulasi ion $\mathrm{Cl}$ pada jaringan tumbuhan yang menyebabkan terjadinya perombakan protein menjadi asam amino, senyawa amida dan amonia. Terganggunya pembentukan klorofil akan mengakibatkan terganggunya proses fotosintesis pada tanaman sehingga akan mengganggu pertumbuhan tanaman mengingat bahwa klorofil merupakan pigmen utama dalam fotosintesis.

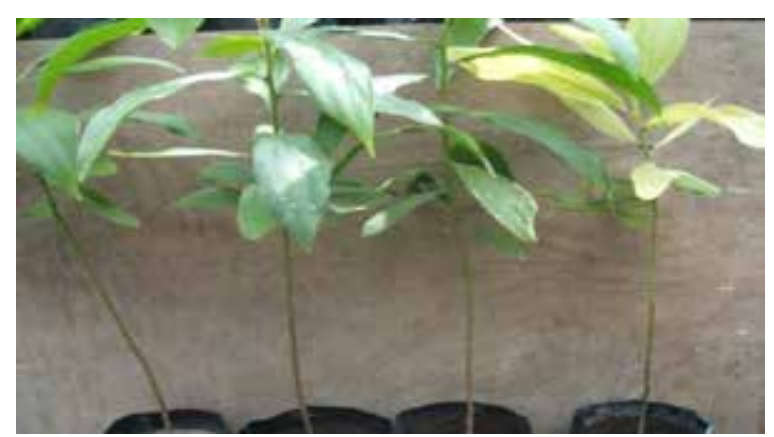

Gambar 4. Gejala Klorosis, dari kiri ke kanan: K0, $\mathrm{K} 1, \mathrm{~K} 2, \mathrm{~K} 3$ (a) daun sehat; (b) daun klorosis

\section{KESIMPULAN}

1. Perlakuan cekaman garam pada $A$. mangium memberikan tanggapan anatomis di antaranya penurunan indeks stomata, ukuran stomata, kadar klorofil dan kenaikan jumlah trakeid yang bervariasi antar sumber benih.

2. Adanya tanggapan anatomis yang beragam tersebut dimungkinkan karena adanya faktor genetis dari masingmasing sumber benih.

3. Secara keseluruhan tanaman A. mangium masih mampu tumbuh pada kondisi cekaman garam sampai dengan $30 \mathrm{~g} / 1$ dan kebun benih semai yang berasal dari provenan Papua New Guinea (grup B) mempunyai ketahanan yang lebih baik dibandingkan dengan provenan lain pada pemberian cekaman garam sampai dengan $30 \mathrm{~g} / 1$.

\section{DAFTAR PUSTAKA}

Devlin, R.M. \& F.H. Witham. 1983. Plant Physiology. W Grant Press. Boston.

Dolatabadian, A., S. A. M. M. Sanavy \& F. Ghanati. 2011. Effect of Salinity on Growth, Xylem Structure and Anatomical Characteristics of Soybean. Notulae Scientia Biologicae. 3 (1) : 41-45

Follet, R.H., L.S. Murphy \& R.I. Donahuc. 1981. Fertilizer and Soil Amandements. Prentice Hall. Inc. Englewood. New Jersey.

Harborne, J. B.1987. Metode Fitokimia : Penentuan Cara Modern Menganalisis Tumbuhan. Penerbit ITB, Bandung.

Hardiyanto, E.B. 2004. Silvikultur dan Pemuliaan Acacia mangium. Dalam: Hardiyanto, E.B dan Hardjono, A. (eds). Pembangunan Hutan Tanaman Acacia mangium Pengalaman di PT. Musi Hutan Persada. PT Musi Hutan Persada. 
Sumatera Selatan.

Harjadi, S.S. dan S. Yahya, 1988. Fisiologi Stres Tanaman. PAU IPB, Bogor

Hendrati, R.L. 2010. Respon Populasi Eucalyptus occidentalis Terhadap Seleksi Kondisi Garam Tinggi Pada Uji Terkontrol dan Uji Lapangan. Jurnal Pemuliaan Tanaman Hutan 4 (2) : 91-100

Johansen, D. A. 1940. Plant Microtechnique. McGraw-hill book company. New York.

Levitt, J.1980. Respon of Plants to Environment Stress Vol. II. Water, Radiation, Salt and Other Stress. Academic Press. New York.

Neumann, P. M., E.V.Volkenburgh, and R.E.Cleland. 1988. Salinity Stress Inhibits Bean Leaf Expansion By Reducing Turgor, Not Wall Extensibility. Plant Physiol. 88 : 233-237.

Nirsatmanto. A., T. Setyaji, S. Sunarti. 2003. Laporan hasil penelitian: Populasi Pemuliaan Untuk Jenis Unggulan Kayu Pulp. BBPBPTH Yogyakarta (tidak dipublikasikan).

Palit, J. 2008. Teknik Penghitungan Jumlah Stomata Beberapa Kultivar Kelapa. Buletin Teknik Pertanian 13 (1).

Pessarakli, M. 1994. Respon of Green Beans (Phaseolus vulgaris L.) to Salt Stress in Handbook of Plant and Crop Physiology.
Marcel Dekker, Inc. New York.

Price, A, and B. Courtois. 1991. Mapping QTLs Associated with Drought Resistance in Rice; Progress Problem and Prospect. Los Banos: International Rice Research Institute.

Pinyopusarerk, K.,S.B. Liang dan B.V. Gunn. 1993. Taxonomy, Distribution, Biology and Use as an Exotic. Dalam: Awang. K. \& D. Taylor. (eds). Acacia mangium Growing and utilization. Winrock International and The Food and FAO. Bangkok. Thailand.

Sipayung, R. 2003. Stres Garam dan Mekanisme Toleransi pada Tanaman. Fakultas Pertanian Jurusan Budidaya Pertanian, Universitas Sumatera Utara.

Strogonov, B. P. 1964. Physiology basic of salt tolerance of plants (Translated from Russian original (1962) by PoljakoffMayber, A) Israel Program for Science. Jerusalem.

Yuniati, R. 2004. Pelapisan Galur Kedelai Glycine max (L.) Merrill Toleran Terhadap NaCl Untuk Penanaman di Lahan Salin. Makara Journal of Science. 8 (1) : 21-24. 